\title{
MODEL PEMBELAJARAN INKUIRI TERBIMBING DENGAN APLIKASI ZOOM UNTUK MENINGKATKAN PROSES DAN HASIL BELAJAR FISIKA MATERI LISTRIK DINAMIS
}

\author{
Yissia Efli Risli Buka, Tineke Makahinda, Alfrits Komansilan \\ Fakultas Matematika dan Ilmu Pengetahuan Alam, Universitas Negeri Manado \\ email: yissiabuka@gmail.com
}

\begin{abstract}
ABSTRAK
Inkuiri terbimbing merupakan proses yang bervariasi dan meliputi kegiatan-kegiatan mengobservasi, merumuskan pertanyaan yang relevan, melaksanakan percobaan atau eksperimen pada siswa. Penelitian tentang model pembelajaran inkuiri terbimbing dengan aplikasi zoom untuk meningkatkan proses dan hasil belajar fisika materi listrik dinamis Penelitian ini bertujuan untuk mengetahui model pembelajaran inkuri terbimbing dengan aplikasi zoom untuk meningkatkan proses dan hasil belajar fisika materi listrik dinamis. Penelitian ini dilaksanakan di SMA N 1 Remboken pada kelas XII IPA 1 dan XII IPA 2. Metode penelitian ini adalah penelitian eksperimen. Data penelitian berdasarkan hasil posttest. Rata-rata hasil belajar siswa yang di berikan perlakuan dengan model pembelajaran inkuiri terbimbing dengan aplikasi Zoom adalah 64,966667 dengan skor maksimum 87 dan skor minimum 46. Sedangkan rata-rata hasil belajar siswa yang di berikan perlakuan pembelajaran tanpa inkuiri terbimbing dengan apilaksi Zoom adalah 58,48387097 dengan skor maksimum 78 dan skor minimum 44. Dari data tersebut dilakukan uji normalitas data yang menunjukan $L_{\text {hitung }}<L_{\text {tabel }}$ artinya data kelas eksperimen dan kontrol tersebut berdistribusi normal, kemudia dilakukan uji hipotesis. Data hasil belajar siswa diperoleh dari posttest. Hasil penelitian dengan perhitungan rumus uji-t satu arah menunjukan bahwa pada model pembelajaran inkuiri terbimbing dengan aplikasi Zoom nilai $t_{\text {hitung }}=2,9920534101>t_{\text {tabel }}=$ 2,00099538 maka tolak $H_{0}$. Sehingga dapat disimpulkan bahwa rata-rata hasil belajar siswa dengan menggunakan model pembelajaran inkuiri terbimbing dengan aplikasi Zoom lebih dari ratarata hasil belajar siswa dengan menggunakan pembelajaran tanpa inkuiri terbimbing.
\end{abstract}

Kata kunci : Model Pembelajaran Inkuiri Terbimbing, Proses Belajar, Hasil Belajar

\begin{abstract}
The guided investigation is a varied process and includes observing activities, formulating relevant questions, performing experiments, or experiments on students. Research on guided exploratory learning models with zoo applications to improve the process and learning outcomes of physical dynamic electrical material. This study aims to determine the Inkuri guided learning model with the Zoom application to improve the process and learning outcomes of dynamic electrical materials physics. This research was carried out on SMA N 1 Remboken in Class XII IPA 1 and XII IPA 2. This research method is experimental research. Research data based on post-test results. The average learning outcomes of students treated with the guided query learning model using the Zoom application was 64.966667 with a maximum score of 87 and a minimum score of 46 . While the average learning outcomes of students who were treated with the Zoom application Application guided learning without guided inquiry were 58.48387097 with a maximum score of 78 and a minimum score of 44 . From the data, the data normality test was performed, which showed $L_{\text {count }}$ $<L_{\text {table, }}$ which means that the experimental and control class data were normally distributed, then a hypothesis test was carried out. Data on student learning outcomes from the post-test. The results of the research by calculating the one-way T-test formula show that in the learning model for guided queries with the zoom application, the value of $t_{\text {count }}=2.9920534101>t_{\text {table }}=2.00099538$ and then $H_{0}$ is rejected. It can therefore be concluded that the average learning outcomes of the students using the guided inquiry learning model with the Zoom application are higher than the average learning outcomes of the students using the guided inquiry learning.
\end{abstract}

Keywords $\quad$ : Guided inquiry learning model, learning process, learning outcomes 


\section{PENDAHULUAN}

Fisika merupakan salah satu cabang Ilmu Pengetahuan Alam (IPA) yang mempunyai karakteristik sehingga pembelajara fisika seharusnya dilakukan sesuai dengan karakteristik fisika yaitu sesuai hakikatnya (Fauziah, 2019). Hakikat belajar sains bukan saja sekedar mengingat dan memahmi konsep yang ditemukan oleh ilmuwan yaitu menemukan konsep. Penemuan konsep ini dilakukan melalui percobaan dan penelitian ilmiah (Mustafit, 2009).

Adapun faktor yang mempengaruhi hasil belajar fisika bisa bersumber dari siswa, guru, alat, dan lingkungan. Faktor yang bersumber dari siswa yaitu keaktifan siswa, bagaimana siswa menunjukkan adanya jiwa aktif, jiwa mengolah informasi, tidak sekedar menyimpannya tanpa mengadakan tranformasi (Rusman, dkk, 2011:24). Penyebab selanjutnya bersumber dari guru yaitu strategi yang digunakan guru belum inovasi, model pun belum bervariasi ataupun kurangnya guru dalam peguasaan materi.

Dari masalah yang di dapati masih banyak siswa yang memiliki hasil belajar yang kurang, karena di sekolah tersebut guru masi menggunakan metode cerama. Kegiatan pembelajaran masih berpusat pada guru, guru hanya menjelaskan materi saja sehingga siswa termotivasi untuk belajar siswa masih sulit memahami materi dengan baik.dan untuk mengatasi permasalahan yang dijelasakan diatas guru perlu memilki model pembelajaran yang menciptakan suasana pembelajaran yang menyenangkan, siswa terlibat aktif serta komunikasi yang terjadi tidak hanya satu arah dari guru ke siswa sehingga siswa dapat memahami materi dengan baik. Model pembelajaran Inkuiri Terbimbing adalah suatu model pembelajaran yang dapat dipilih untuk menciptakan pembelajaran yang menyenangkan dan membuat seluruh siswa terlibat aktif dalam pembelajaran. Dengan adanya keaktifan siswa dalam pembelajaran diharapkan tercipta proses pembelajaran yang menyenangkan dan meingkatkan minat siswa untuk belajar sehingga hasil belajar pun akan meningkat.

Pada masa sekarang ini, dunia dihadapkan dengan fenomena yang berkaitan dengn masalah kesehatan yaitu virus corona atau COVID-19, banyak negara yang terkena dampak virus ini, Indonesia termasuk salah satunya. Untuk itu pemerintah mengambil kebijakan dengan menerapkan social distancing untuk meminimalis penularan COVID-19. Dalam situasi yang ada saat ini guru dituntut untuk tetap melaksanakan pembelajaran yang dibantu dengan beberapa media pembelajaran berbasis online, salah satunya menggunakan zoom untuk melaksanakan pembelajaran dengan bertatap muka secara virtual antara guru dengan siswa.

Berdasarkan uraian diatas, maka penulis tertarik melakukan penelitian untuk meneliti tentang hasil belajar fisika siswa berdasarkan model pembelajaran Inkuiri Terbimbing. Maka penulis melakukan penelitian dengan judul "Model pembelajaran Inkuiri Terbimbing dengan aplikasi zoom untuk meningkatkan proses dan hasil belajar fisika materi listrik dinamis". Adapun tujuan yang ingin dicapai dalam penelitian ini untuk mengetahui model pembelajaran inkuri terbimbing dengan aplikasi zoom untuk meningkatkan proses dan hasil belajar fisika materi listrik dinamis.

\section{METODE PENELITIAN}

Tempat dan Waktu Penelitian

Penelitian ini dilaksanakan di SMA N 1

Remboken pada semester genap tahun ajaran 2021/2022

\section{Populasi dan Sampel}

1. Populasi

Populasi dalam penelitian ini adalah siswa kelas XII IPA 1 dan XII IPA 2 SMA N 1 Remboken tahun ajaran 2021/2022

2. Sampel

Yang menjadi sampel dalam penelitian ini adalah siswa kelas XII IPA 1 yang berjumlah 31 orang siswa dan kelas XII IPA 2 berjumlah 30 orang siswa di SMA N 1 Remboken

\section{Jenis dan Desain Penelitian}

Berdasarkan judul dan permasalahan di atas maka jenis penelitain ini adalah eksperimen. Dalam penelitian ini, siswa dibedakan atas dua kelas yaitu kelas control dan kelas eksperimen. Kedua kelas ini diberi perlakuan yang berbeda. Pada kelas eksperimen digunakan Model Pembelajaran Inkuiri Terbimbing, sedangkan kelas control digunakan pembelajaran tanpa model inkuiri terbimbing.

Desain eksperimen yang digunakan dalam 
penelitian ini berbentuk Randomized Posstest Only Control Group Design. Responden benarbenar dipilih secara random dan diberi perlakuan untuk lebih jelasnya dapat dilihat pada tabel.

Tabel 1. Desain Penelitian

\begin{tabular}{llcc}
\hline & Kelompok & Perlakuan & postes \\
& & & \\
\hline (R) & Eksperimen & $X_{1}$ & $Y_{2}$ \\
& & & \\
\hline (R) & Control & $X_{2}$ & $Y_{2}$
\end{tabular}

Keterangan :

$\mathrm{R}:$ Random

$X_{1}$ : Perlakuan penelitian, pembelajaran model Inkuiri terbimbing

$X_{2}$ : Perlakuan penelitian, pembelajaran tanpa model inkuiri terbimbing

$Y_{2}$ : postes setelah perlakuan

\section{Variabel penelitian}

Terdapat dua variable dalam penelitian ini, yaitu:

1. Variabel Bebas

Variable bebas pada penelitian ini yaitu model inkuiri terbimbing dan pembelajaran langsung dengan menggunakan zoom.

2. Variabel Terikat

Variabel terikat pada penelitian ini yaitu hasil belajar siswa (nilai post-test setelah diberi perlakuan).

\section{Instrumen Penelitian}

Instrument dalam penelitian ini terdiri dari perangkat pembelajaran dan tes hasil belajar di antaranya :

1. Perangkat pembelajaran meliputi RPP sebanyak 2 macam. Satu untuk kelas eksperimen dan satu untuk kelas kontrol

2. Tes hasil belajar

Sebelum dilaksanakan tes hasil belajar terlebih dahulu dilakukan uji validasi dimana penelitian meminta pendapat kepada dosen pembimbing dan guru mata pelajaran tentang tes yang dibuat apakah layak untuk digunakan.

\section{Teknik Pengumpulan Data}

Pengumpulan data dalam penelitian ini dilakukan dengan cara memberikan tes dalam bentuk uraian kepada siswa dari kedua kelas baik kelas eksperimen maupun kelas kontrol, kemudian dikerjakan oleh siswa. Setelah itu, hasil pekerjaan siswa dikumpulkan oleh peneliti untuk kemudian dievaluasi, diperikasa dan diberi skor. Hasil evaluasi penelitian pekerjaan siswa tersebut akan dijadikan data dalam penelitian ini.

\section{Teknik Analisis Data}

Analisis data dengan uji t digunakan untuk menguji hipotesis . statistik inferensial adalah teknik statistik yang digunakan untuk menganalisis data sampel dan hasilnya diberlakukan untuk populasi. Teknik statistik ini dimaksudkan untuk menguji hipotesis penelitian. sebelum menguji hipotesis penelitian, dilakukan uji normlitas dan uji homogenesis sebagai uji persayaratan, uji persyaratan ini dilakukan berdasarkan paduan tentang pengujian perbandingan rata-rata dua kelompok tidak berpasangan (uji $\mathrm{t}$ tidak berpasangan ) yang diadaptasi dari (Lolombulan, 2017).

$t=\frac{\left(\overline{X_{1}}-\overline{X_{2}}\right)}{s \sqrt{\left(\frac{1}{n_{1}}\right)+\left(\frac{1}{n_{2}}\right)}}$ bila ragam kedua kelompok sama atau $\sigma_{1}^{2}=\sigma_{2}^{2}$

$S=\sqrt{\frac{\left(n_{1}-1\right) S_{1}^{2}+\left(n_{2}-1\right) S_{2}^{2}}{n_{1}+n_{2}-2}}=$ simpangan baku gabungan kedu kelompok Statistika uji t rumus 1 memiiki db $=n_{1}+n_{2}-2$ $t=\frac{\left(\overline{X_{1}}-\overline{X_{2}}\right)}{\sqrt{\frac{s_{1}^{2}}{n_{1}}+\frac{s_{2}^{2}}{n_{2}}}}$ bila ragam kedua kelomok berbeda atau $\sigma_{1}^{2} \neq \sigma_{2}^{2}$

Statistik uji rumus 2 memiliki db

$$
=\frac{\left(\frac{s_{1}^{2}}{n_{1}}+\frac{s_{2}^{2}}{n_{2}}\right)}{\frac{\left(s_{1}^{2} / n_{1}\right)^{2}}{n_{1}-1}+\frac{\left(s_{2}^{2} / n_{2}\right)}{n_{2}-1}}
$$

$S_{1}^{2}=\frac{n_{1} \sum x_{1}^{2}-\left(\sum x_{1}^{2}\right)^{2}}{n_{1}\left(n_{1}-1\right)}$

$S_{2}^{2}=\frac{n_{2} \sum x_{2}^{2}-\left(\sum x_{2}^{2}\right)^{2}}{n_{2}\left(n_{2}-1\right)}$

$\overline{X_{1}}=\frac{\sum X_{1}}{n_{1}} \operatorname{dan} \overline{X_{2}}=\frac{\sum X_{2}}{n_{2}}$

Dimana :

$\overline{X_{1}}=$ rata-rata skor tes akhir pada kelas eksperimen

$\overline{X_{2}}=$ rata-rata skor tes akhir pada kelas control

$n_{1}=$ jumlah siswa kelas eksperimen

$n_{2}=$ jumlah siswa kelas control

$S_{1}=$ simpangan baku skor kelas eksperimen

$S_{2}=$ simpangan baku skor kelas control 
$S=$ simpangan baku gabungan kedua skor Apabilah subjek pada kedua perlakuan lebih dari atau sama dengan 30, maka uji kenormalan data tidak perlu dilakukan. Apabila subjek kurang dari 30, maka perlu dilakukan uji normalitas sebagai uji prasyarat untuk menggunakan uji t. Statistik uji yang digunakan untuk pengujian kenormalan data adalah statistik uji Lilliefors. Adapun untuk menentukan uji $\mathrm{t}$ mana yang akan digunakan diperlukan uji homogenesis atau uji kesamaan varians. Statistik uji yang digunakan untuk menguji kesamaan varians adalah uji $\mathrm{F}$ dengan Rumus :

$$
F \frac{\text { varians terbesar }}{\text { varians terkecil }}
$$

$H_{0}=$ Rata-rata hasil belajar siswa menggunakan model Inkuiri Terbimbing tidak berbeda dari hasil belajar siswa dengan menggunakan model pembelajaran direct instruction.

$H_{1}=$ Rata-rata hasil belajar siswa menggunakan model pembelajaran Inkuiri Terbimbing lebih baik dari hasil belajar siswa dengan menggunakan model pembelajaran tanpa inkuiri terbimbing.

\section{Hipotesis Statistik}

$$
\begin{aligned}
& H_{0}: \mu_{1} \leq \mu_{2} \\
& H_{1}: \mu_{1}>\mu_{2}
\end{aligned}
$$

Keterangan :

$$
\begin{array}{cl}
\mu_{1} \quad \text { : rata-rata hasil belajar siswa } \\
\text { menggunakan model pembelajaran } \\
\text { Inkuiri Terbimbing } \\
\mu_{2} \quad \text { : rata-rata belajar siswa menggunakan } \\
\text { model pembelajarn direct instruction }
\end{array}
$$

\section{HASIL DAN PEMBAHASAN}

Penelitian ini dilaksanakan di SMA Negeri 1 Romboken pada semester genap tahun ajaran 2021/2022 pada kelas yang terpilih, yaitu siswa kelas XII IPA 1 sebagai kelas kontrol dengan jumlah 31 siswa dan siswa kelas XII IPA 2 sebagai kelas eksperimen dengan jumlah 30 siswa. Penelitian menerapkan pembelajaran dengan menggunakna model pembelajaran Inkuiri Terbimbing dengan aplikasi Zoom pada materi Listrik Dinamis.

Data ini di ambil dari hasil posttest materi Listrik Dinamis dengan rentang nilai 0-100. Data hasil posttest pada kelas eksperimen dan kontrol dapat di lihat dari tabel berikut :
Tabel 2. Statistik Nilai Posttest Kelas Eksperimen

\begin{tabular}{llll}
\hline No & Statistik & Nilai Statistik \\
\cline { 3 - 4 } & & $\begin{array}{l}\text { Kelas } \\
\text { Eksperimen }\end{array}$ & $\begin{array}{l}\text { Kelas } \\
\text { Kontrol }\end{array}$ \\
\hline 1. & Jumlah & 1949 & 1813 \\
\hline 2. & Nilai Min & 46 & 44 \\
\hline 3. & Nilai & 87 & 78 \\
& Max & & \\
\hline 4. & Rata-rata & 64.966667 & 58.48387097 \\
\hline 5. & S. deviasi & 8.6999141 & 8.221398777 \\
\hline 6. & Varians & 75.688506 & 67.59139785 \\
\hline
\end{tabular}

Pada data hasil penelitian yang didapat yang tertera pada tabel di atas, diketahui pada posttest untuk kelas eksperimen data terendah adalah 46 dan data yang tertinggi adalah 87 sedangkan pada kelas kontrol data terendah adalah 44 dan data yang tertinggi adalah 78 .

Tabel 3. Distribusi Frekuensi Posttest Kelas Eksperimen

\begin{tabular}{ll}
\hline Interval kelas & Frekuensi \\
\hline $46-52$ & 1 \\
\hline $53-59$ & 8 \\
\hline $60-66$ & 10 \\
\hline $67-73$ & 6 \\
\hline $74-80$ & 4 \\
\hline $81-87$ & 1 \\
\hline
\end{tabular}

Tabel 4. Distribusi Frekuensi Posttest Kelas Kontrol

\begin{tabular}{ll} 
Interval kelas & Frekuensi \\
\hline $44-48$ & 3 \\
\hline $49-54$ & 8 \\
\hline $55-60$ & 7 \\
\hline $61-66$ & 9 \\
\hline $67-72$ & 1 \\
\hline $73-78$ & 3 \\
\hline
\end{tabular}

Adapun data-data tersebut dituangkan dalam bentuk Histogram dibawah ini :

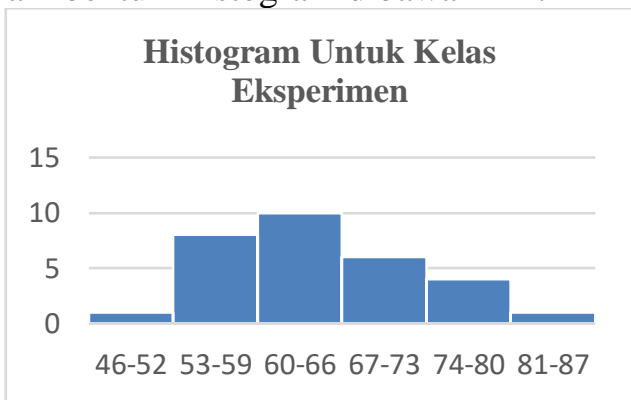

Gambar 1. Histogram Untuk Kelas Eksperimen 


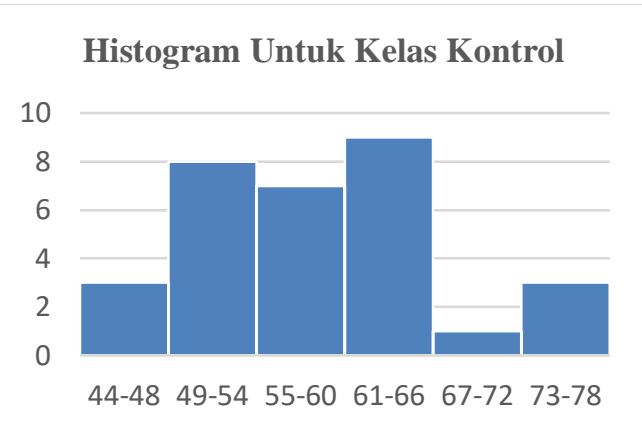

Gambar 2. Histogram Untuk Kelas Kontrol

Sebelum dilakukan pengujian hipotesis dengan menggunakan uji-t, terlebih dahulu dilakukan uji normalitas data menggunakan uji normalitas dan uji homogenitas varians. Data yang digunakan adalah data selisih Posttest dari kedua kelas yaitu kelas eksperimen dan kelas kontrol.

\section{Uji Prasyarat}

Uji normalitas data pada penelitian ini menggunakan uji liliefors yang diolah menggunakan software Microsoft Excel. Hasil uji normalitas dari Posttest pada kelas eksperimen menunjukan nilai $L_{\text {hitung }}=$ 0.0860601 dan $L_{\text {tabel }}=0.1617607$, karena $L_{\text {hitung }}<L_{\text {tabel }}$ maka terima $H_{0}$ dan data berdistribusi normal.

Sementara uji noralitas dari Posttest pada kelas kontrol menunjukan nilai $L_{\text {hitung }}=$ 0.1348498 dan $L_{\text {tabel }}=0.1591303$, karena $L_{\text {hitung }}<L_{\text {tabel }}$ maka terima $H_{0}$ dan data berdistribusi normal.

Uji Homogenitas

Hasil analisis pengujian kesamaan dua varians/ragam dengan statistik uji $\mathrm{F}$ pada data selisih posttest dengan $S_{E}^{2}=8,69991412$ dan $S_{K}^{2}=8,22139878$ memberi nilai $F_{\text {hitung }}=1.119794947 \quad$ sedangkan nilai $F_{\text {tabel }}=f_{0,05(30,31)} 1.847427828 \quad$ maka terima $H_{0}: \sigma_{1}^{2}=\sigma_{2}^{2}$. Jadi, dapat dilihat bahwa varians dari kedua kelas control dan eksperimen adalah homogeny atau sama.

\section{Pengujian Hipotesis}

Dari hasil pengujian hipotesis dengan uji-t pada taraf nyata $\alpha=0,05$ diperoleh $t_{\text {hitung }}=2,992053410$ dan nilai $t_{\text {tabel }}=$ $t_{0,05(59)}=2.00099538$ yang artinya statistik uji tersebut jatuh dalam wilaya kritis. Berdasarkan kriteria pengujian hipotesis yaitu tolak $H_{0}$ jika statistik uji jatuh dalam wilayah kritis maka dapat disimpulkan bahwa rata-rata hasil belajar siswa dengan menggunakan model pembelajaran inkuiri terbimbing dengan aplikasi Zoom lebih dari rata-rata hasil belajar siswa dengan menggunakan pembelajaran tanpa model inkuiri terbimbing.

\section{KESIMPULAN}

Berdasarkan hasil penelitian siwa kelas XII IPA 1 dan XII IPA 2 di SMA Negeri 1 Remboken dalam pemelajaran fisika khususnya pada materi listrik dinamis dapat di tarik kesimpulan bahwa : untuk kelas eksperimen rata-rata hasil belajar siswa yang diberikan perlakuan dengan menggunakan model pembelajaran inkuiri terbimbing adalah 64,966667 dengan skor maksimum 87 dan skor minimum 46, sedangkan untuk kelas kontrol rata-rata hasil belajar siswa yang diberikan perlakuan pembelajaran tanpa model inkuiri terbimbing adalah 58,48387097 dengan skor maksimum 78 dan skor minimum 44.

Dari hasil pengujian hipotesis dengan menggunakan statistic uji-t satu arah dengan taraf nyata $(\alpha)=0,05$ diperoleh hasil $t_{\text {hitung }}>t_{\text {tabel }}$ sehingga menolak $H_{0}$ dan menerima $H_{1}$. Dengan demikian dapat ditarik suatu kesimpulan bahwa berdasarkan hasil belajar siswa yang diajarkan menggunakan model pembelajaran inkuiri terbimbing lebih tinggi dari hasil belajar siswa yang menggunakan pembelajaran tanpa inkuiri terbimbing.

\section{REFERENSI}

Danin Haqien, A. A. (2020). Vol 5, No 1. Pemanfaatan Zoom Meeting Untuk Proses Pembelajaran Pada Masa Pandemi COVID-19, 51.

Lolombulan, H. J. (2017). Statistika Bagi Peneliti Pendidikan. Yogyakarta: Andi. .

Mustafit, N. (2009). Universitas Negeri Semarang, MIPA. Semarang : Nurul Mustafi. Implementasi Problem Solving Laboratory sebagai Model Kegiatan Laboratorium Berbasis Inquiri Terbimbing untuk Meningkatkan Pemahaman Konsep Kesetimbangan Benda pada Mahasiswa Pendidikan Fisika Semester II Tahun Ajaran 2007/2008 